Student Scholarship

$3-5-2012$

\title{
DoMA Statutes and Same-Sex Divorce Litigation
}

Erica A. Holzer

William Mitchell College of Law

Follow this and additional works at: http://open.mitchellhamline.edu/stusch

Part of the Constitutional Law Commons, and the Family Law Commons

\section{Recommended Citation}

Holzer, Erica A., "DoMA Statutes and Same-Sex Divorce Litigation" (2012). Student Scholarship. Paper 2.

http://open.mitchellhamline.edu/stusch/2 


\section{DoMA Statutes \& Same-Sex Divorce Litigation \\ Updated January 31, 2011 \\ Erica Holzer}

For the purposes of writing a article on same-sex divorce, it became necessary to categorize the various state Defense of Marriage Act (DoMA) statutes and constitutional amendments to analyze how each type of DoMA might handle a petition for same-sex divorce. In doing so, I developed six different categories: (1) No DoMA; (2) Definitional DoMAs; (3) DoMAs that void same-sex marriages; (4) DoMAs that explicitly deny benefits of marriage; (5) DoMAs that declare that there is no same-sex marriage to dissolve; and (6) DoMAs that explicitly prohibit same-sex divorce. This document shows which state DoMAs fall into each of these categories.

The states listed in each category are also color coded to show if there is same-sex divorce caselaw precedent in that jurisdiction and, if so, whether same-sex divorce was granted or denied. States listed in blue have no caselaw on record; states listed in red have caselaw on record denying same-sex divorce, and states listed in green have caselaw on record granting same-sex divorce.

\section{$\underline{\text { KEY }}$}

No Same-Sex Divorce Caselaw on Record

Caselaw Denying Same-Sex Divorce

Caselaw Granting Same-Sex Divorce

\section{No DoMA}

a. No DoMA and grants same-sex marriage ${ }^{1}$

i. Massachusetts, Connecticut, Iowa, Vermont, New Hampshire, New York, District of Columbia

b. No DoMA and grants civil unions

i. Delaware, Hawaii, Illinois, New Jersey, Rhode Island

c. No DoMA but recognizes same-sex marriages from other states

i. California (if performed before Nov. 8, 2011)

d. No DoMA and does not recognize same-sex marriages from other states

i. New Mexico (granted a divorce), Wyoming (inconsistent statutes - refused to grant divorce, case pending), Guam

\footnotetext{
${ }^{1}$ Legislation passed in Washington and Maryland in February 2012 will allow same-sex marriages, but those laws have not yet taken effect. In California, a federal appeals court found that the state constitution's restriction on samesex marriage was invalid, but has postponed enforcement pending appeal. Defining Marriage: Defense of Marriage Acts and Same-Sex Marriage Laws, NAT’L CONFERENCE OF STATE LEGISLATURES (Feb. 24, 2012), http://www.ncsl.org/issues-research/human-services/same-sex-marriage-overview.aspx.
} 


\section{Definitional DoMAs}

These DoMAs are intended to define marriage; they say nothing about same-sex divorce, nor do they declare same-sex marriages void.

a. These DoMAs define marriage as between one man and one woman:

i. Colorado, Hawaii, Idaho, Maryland, Missouri Const., North Carolina, Oregon

\section{DoMAs that void same-sex marriages}

These DoMAs also define marriage as between one man and one woman, but go beyond definitional DoMAs in that they also define the status of same-sex marriages in other states. Some of these DoMAs explicitly state that the public policy of the state is against same-sex marriage.

a. These DoMAs state that same-sex marriage is void, even if lawful in the place where solemnized:

i. Indiana (uses "gender"), Kansas, Michigan, Mississippi Const. (and unenforceable), Nevada Const. (only male/female shall be recognized and given effect), Pennsylvania

b. These DoMAs state that same-sex marriage is void and against public policy:

i. Idaho, Kansas, Louisiana, Michigan, Pennsylvania, Tennessee

\section{DoMAs that explicitly deny benefits of marriage}

These DoMAs define marriage as between one man and one woman, state that same-sex marriages are void, and explicitly deny any benefits of marriage to same-sex couples even if those couples were validly married in other states.

a. These DoMAs state that same-sex marriages shall not be recognized:

i. Alabama (as valid), Alaska, Arkansas Const., Florida (for any purpose), Georgia Const., Georgia, Kentucky Const. (legal status), Louisiana Const., Louisiana (for any purpose), Michigan Const. (for any purpose), Mississippi Const., Missouri (for any purpose), Nebraska Const., North Dakota Const. (or given the same or substantially equivalent legal effect), Ohio Const. (shall not create or recognize a legal status for unmarried couples that intends to approximate the design, qualities or significance or effect of marriage), Oklahoma Const. (as of the date of the marriage), Oklahoma (as of the date of the marriage), South Dakota Const. (including civil union, domestic partnership, or other quasi-marital relationship), Texas Const. (may not create or recognize any legal status identical or similar to marriage), Utah Const. (or give the same or substantially equivalent legal effect), Utah (recognize, enforce, or give legal effect), Virginia Const. (shall not create or recognize a legal status for relationships of unmarried individuals that intends to approximate the design, qualities, significance, or effects of marriage; shall not create or recognize another union, partnership, or other legal status to which is assigned the rights, benefits, obligations, qualities, or effects of 
marriage), Virginia (void in all respects, includes civil unions), Wisconsin (includes a legal status identical or substantially similar to marriage), Puerto Rico (includes transsexuals)

b. These DoMAs state that same-sex marriages are prohibited:

i. Arizona, Delaware, Georgia Const., Georgia, Illinois, Kentucky, Maine, Minnesota, Mississippi (same gender), Montana, Utah, Virginia (includes civil unions), Washington

c. These DoMAs state that, for same-sex couples married validly in other states, contractual rights granted by virtue of the marriage, including its termination, are unenforceable in this state:

i. Alaska, Arkansas, Kentucky (any rights), Minnesota, Virginia (includes civil unions)

d. These DoMAs state that same-sex marriages validly performed in other states may not be recognized by the state as being entitled to the benefits of marriage:

i. Alaska, Georgia Const., Georgia, Louisiana Const. (legal incidents of marriage), Louisiana (assertion of any right or claim as a result of the purported marriage), Oklahoma Const. (legal incidents of marital status)

e. These DoMAs state that the state, its agencies, and its political subdivisions may not give effect to any public act, record, or judicial proceeding respecting either a marriage or other relationship not recognized by the state, or a claim arising from such a marriage or relationship:

i. Florida, Georgia Const., Georgia, Texas (may not give effect to a public act, record, or judicial proceeding that creates, recognizes, or validates a marriage between persons of the same-sex or a civil union in this state or in any other jurisdiction), West Virginia

f. These DoMAs state that parties may not evade the laws of the state by going to another state to marry:

i. Arizona, Idaho, Maine (void)

g. These DoMAs state that evasive marriages are treated as if the marriage was performed in this state:

i. Delaware, Illinois, Mississippi (null and void from the beginning), Wisconsin (very extensive evasive marriage statute)

\section{DoMAs that declare that there is no same-sex marriage to dissolve}

These DoMAs define marriage as between one man and one woman, state that same-sex marriages are void, and explicitly state that there is no same-sex marriage to dissolve.

a. This DoMA states that any same-sex marriage is void and dissolved without legal process:

i. Maine

b. These DoMAs state that any same-sex marriage is null and void from the beginning:

i. Mississippi, South Carolina (void ab initio) 
c. These DoMAs state that the state may not give effect to any right or claim to any legal protection, benefit, or responsibility asserted as a result of a marriage between persons of the same-sex or a civil union in this state or in any other jurisdiction:

i. Texas, Utah (will not recognize, enforce, or give legal effect to any law creating any legal status, rights, benefits, or duties that are substantially equivalent to those provided under Utah law to a man and a woman because they are married)

\section{DoMAs that explicitly prohibit same-sex divorce}

a. Georgia Const., Georgia

The courts of this state shall have no jurisdiction to grant a divorce or separate maintenance with respect to any such relationship or otherwise to consider or rule on any of the parties' respective rights arising as a result of or in connection with such relationship.

b. Ohio (taken as a whole, indication of legislative intent)

(C)(1) Any marriage between persons of the same sex is against the strong public policy of this state. Any marriage between persons of the same sex shall have no legal force or effect in this state and, if attempted to be entered into in this state, is void ab initio and shall not be recognized by this state.

(2) Any marriage entered into by persons of the same sex in any other jurisdiction shall be considered and treated in all respects as having no legal force or effect in this state and shall not be recognized by this state.

(3) The recognition or extension by the state of the specific statutory benefits of a legal marriage to nonmarital relationships between persons of the same sex or different sexes is against the strong public policy of this state. Any public act, record, or judicial proceeding of this state, as defined in section 9.82 of the Revised Code, that extends the specific statutory benefits of legal marriage to nonmarital relationships between persons of the same sex or different sexes is void ab initio. Nothing in division $(\mathrm{C})(3)$ of this section shall be construed to do either of the following:

(a) Prohibit the extension of specific benefits otherwise enjoyed by all persons, married or unmarried, to nonmarital relationships between persons of the same sex or different sexes, including the extension of benefits conferred by any statute that is not expressly limited to married persons, which includes but is not limited to benefits available under Chapter 4117. of the Revised Code;

(b) Affect the validity of private agreements that are otherwise valid under the laws of this state.

(4) Any public act, record, or judicial proceeding of any other state, country, or other jurisdiction outside this state that extends the specific benefits of legal marriage to nonmarital relationships between persons of the same sex or different sexes shall be considered and treated in all respects as having no legal force or effect in this state and shall not be recognized by this state. 


\begin{tabular}{|c|c|c|c|c|c|}
\hline \multicolumn{6}{|c|}{$\begin{array}{l}\text { DoMA Statutes \& Same-Sex Divorce Litigation } \\
\text { Updated January 31, } 2011\end{array}$} \\
\hline No DOMA & $\begin{array}{l}\text { Definitional } \\
\text { DoMAs }\end{array}$ & $\begin{array}{l}\text { DoMAs that } \\
\text { void same- } \\
\text { sex } \\
\text { marriages }\end{array}$ & $\begin{array}{l}\text { DoMAs that } \\
\text { explicitly } \\
\text { deny benefits } \\
\text { of marriage }\end{array}$ & $\begin{array}{l}\text { DoMAs that } \\
\text { declare that } \\
\text { there is no } \\
\text { same-sex } \\
\text { marriage to } \\
\text { dissolve }\end{array}$ & $\begin{array}{l}\text { DoMAs that } \\
\text { explicitly } \\
\text { prohibit } \\
\text { same-sex } \\
\text { divorce }\end{array}$ \\
\hline $\mathrm{CA}$ & $\mathrm{CO}$ & IN & $\mathrm{AL}$ & ME & $\mathrm{OH}$ \\
\hline CT & $\mathrm{HI}$ & KS & $\mathrm{AK}$ & MN & GA \\
\hline $\mathrm{DC}$ & ID & $\mathrm{PA}$ & $\mathrm{AZ}$ & MS & TX \\
\hline IA & MD & $\mathrm{TN}$ & $\mathrm{AR}$ & MT & \\
\hline MA & MI & & $\mathrm{DE}$ & SC & \\
\hline $\mathrm{NH}$ & NV & & FL & VA & \\
\hline NJ & $\mathrm{NC}$ & & IL & & \\
\hline NM & OR & & KY & & \\
\hline NY & & & LA & & \\
\hline RI & & & MO & & \\
\hline VT & & & $\mathrm{NE}$ & & \\
\hline WY & & & ND & & \\
\hline Guam & & & SD & & \\
\hline \multirow[t]{5}{*}{ Virgin Islands } & & & UT & & \\
\hline & & & WA & & \\
\hline & & & WV & & \\
\hline & & & WI & & \\
\hline & & & Puerto Rico & & \\
\hline
\end{tabular}

